\title{
CDH5 wt Allele
}

National Cancer Institute

\section{Source}

National Cancer Institute. CDH5 wt Allele. NCI Thesaurus. Code C51153.

Human CDH5 wild-type allele is located in the vicinity of $16 q 22.1$ and is approximately 38 $\mathrm{kb}$ in length. This allele, which encodes vascular endothelial-cadherin protein, plays a role in calcium-dependent cell-cell adhesion, endothelial cell cohesion and endothelial survival. 